\title{
A Study to Assess the Level of Comfort among Post Operative Children (Age 5-10 Years) by using Katharine Kolcaba Comfort Observation a Checklist and Comfort Daises at Selected Hospital of Punjab (India)
}

\author{
Sharma Mukesh Chandra M.sc (Pediatric Nursing) ${ }^{1}$, Kalia Raman (M. Sc (N) PhD (N)) ${ }^{2}$ \\ ${ }^{1}$ Associate professor, Amity College of Nursing \\ ${ }^{2}$ Principal Saraswati College of Nursing, Kurali
}

\begin{abstract}
Objective of case study: To assess the level of comfort among post operative children (age 5-10 years). Research approach: Descriptive approach was used in assessing comfort level in post operative child. The tools used for data collection were Base line information of children. Comfort Behavior check list, and Comfort Daisies. Result showed that post operative children were having moderate discomfort (45.88 \pm 9.91$)$ as assessed by comfort observation check list.This finding goes with comfort assessed with comfort daises which involves a child's rating his or her comfort from one to four (very bad to very good) that post operative children averagely rated their comfort feeling between very bad and sort of bad.
\end{abstract}

Keywords: Discomfort, Post operative children (age 5-10 year) child.

\section{Introduction}

Children can perceive hospitalization as one of the most stressful event. Anxiety, fear, withdrawal, depression, regression and defiance are few reactions shown by children as well as adult, and it can be more severe than their reaction to illness. ${ }^{1}$ The hospital situation is frequently unfamiliar, similar to the state in infancy where the unknown is perceived as threatening. Ellerton \& Merriam ${ }^{2}$ evaluated that medical procedure are exceptionally upsetting for youngsters and they have less effective coping behaviors. Schmidt ${ }^{3}$ described the anxiety and emotional disturbances experienced due to hospitalization .Doctors nurses, health routines and health workers creates white uniform phobia in children .Moreover, medical procedures such as injection or I.V. insertion are sources of fear and anxiety in children. As mentioned by Kain zn et. al ${ }^{4}$ revealed that much as $50-60 \%$ of children undergoing surgery shown postoperatively behavioral changes included separation anxiety, sleep disturbance, aggression toward authority, temper tantrum, and eating problems .Nurses document patient's states prior and then afterward the utilization of comfort measures to check if the measures are enhancing or declining the patient's condition. Nurses knowing a patient's condition can provide comfort measures prophylactically to prevent negative outcomes. Correct assessment of level of comfort will guide the nurse to utilize comfort care interventions in decreasing the discomfort. Being able to determine when comfort measures are necessary or useful is vital to improving the quality of patient care .With increased patient comfort; they are more likely to engage in health seeking behaviors.

\section{Aim}

An aim of study was to assess the level of comfort in post operative children age 5-10 years by using Katharine Kolcaba Comfort Observationa Check list and Comfort daises

\section{Material and method}

Research design

Descriptive study selected for describing the level of comfort experiencing by children .Further feasibility of tools checked by their effectiveness in collecting data, usability, and practicability in application of tool.

\section{Research setting}

The study was conducted at Gian Sagar Medical College and Hospital, Deep hospital Ludhiana, Rajindra Hospital of District Patiala, Punjab.

\section{Target population}

In this study target population were post operative children age $5-10$ years.

\section{Sample \& Sampling Technique}

Total 100 samples were selected by using purposive sampling technique. Firstly the researcher located the sample then checked for the inclusion criteria and sample that were fulfilling desire criteria were selected in study.

Inclusive criteria-

- Post operative children had surgery under GA

- Children age 5-10 years

- Children who are conscious. 
Exclusive criteria

- Unconscious children

- Not able to hear, listen and talk.

\section{Data collection method}

Observation method and self report method were used to measure the children post operative comfort .In which Comfort Behaviors Checklist used to observe the patient behavior and comfort daises used as self report way of expressing patient comfort feeling.

\section{Description of tool}

Tool

- Tool I-Base line information of children.

- Tool II-General comfort questionnaire

- Tool III- Comfort Observation check list

- Tool IV -Comfort daises

General comfort questionnaire, comfort observation checklist and comfort daises are tool to assess comfort proposed by Katharine Kolcaba ${ }^{5}$.General Comfort Questionnaire (GCQ) is designed to measure holistic changes in comfort levels. Multiple adaptations of the GCQ have been developed for specific purposes. It composed of 48 items questions (Half positive and half negative items).It covered the content domain of comfort .Comfort behavior checklist -data collectors are used to rate a patient apparent comfort. Comfort daisies, this instrument was designed for use with young children .Children's Comfort Daisies is a more sensitive instrument than the simple question asked above because it involves a child's rating his or her comfort from one to four.

\section{Population}

Post operative Children age 5-10 years

\section{Ethical considerations/Clearance}

Permission was taken from concerned authorities for conducting study.

\section{Data collection procedure}

Data collected in the year 2015-2016.Data were collected after ethical clearance and getting permission from relevant authority. Samples selected by using purposive sampling technique. Post operative discomforts of children assessed by using comfort observation check list and comfort daises. General comfort questionnaire were used to ask children level of comfort, but it was very difficult to get answer from children .Though questionnaire very modified in Hindi, still it was very difficult for them to respond it.Both comfort observation check list and comfort daises were suitable in taking response from children.

\section{Result}

Data were analyzed by using descriptive statistics. In descriptive statistics frequency, percentage, mean and standard deviation were used.

\section{Section A: Sample characteristics}

This section deals with the description of sample characteristics of the subjects.

Table 1: Description of sample characteristics

\begin{tabular}{|c|c|c|c|}
\hline & Variable & Frequency & Percentage \\
\hline 1. & $\begin{array}{l}\text { Age of child? } \\
\text { a)-5-7 year } \\
\text { b) }>7-9 \text { year } \\
\text { c) }>9-10 \text { years }\end{array}$ & $\begin{array}{l}37 \\
33 \\
30\end{array}$ & $\begin{array}{l}37 \% \\
33 \% \\
30 \%\end{array}$ \\
\hline 2. & $\begin{array}{l}\text { Sex of the child? } \\
\text { a) Male } \\
\text { b) Female }\end{array}$ & $\begin{array}{l}56 \\
44 \\
\end{array}$ & $\begin{array}{l}56 \% \\
44 \%\end{array}$ \\
\hline 3. & $\begin{array}{l}\text { Education of Child } \\
\text { a) No formal education } \\
\text { b) Under first class } \\
\text { c) }>1^{\text {st }} \text { to } 3^{\text {rd }} \\
\text { d) }>3^{\text {rd }} \text { to above }\end{array}$ & $\begin{array}{c}5 \\
15 \\
61 \\
19\end{array}$ & $\begin{array}{l}5 \% \\
15 \% \\
61 \% \\
19 \% \\
\end{array}$ \\
\hline 4. & $\begin{array}{l}\text { Who is Primary care giver? } \\
\text { a) Father } \\
\text { b) Mother } \\
\text { c) Grand mother } \\
\text { d) Grand father } \\
\text { e) Aunty } \\
\text { f) Uncle } \\
\text { g) Maid } \\
\text { h) Any other ...than specify }\end{array}$ & $\begin{array}{c}1 \\
79 \\
15 \\
--- \\
5 \\
- \\
-- \\
- \\
\end{array}$ & $\begin{array}{c}1 \% \\
79 \% \\
15 \% \\
---- \\
5 \% \\
- \\
-- \\
-\end{array}$ \\
\hline 5. & $\begin{array}{l}\text { Number of previous hospitalization } \\
\text { a) Nil (Admitted for the first } \\
\text { time) } \\
\text { b) one time } \\
\text { c) two times } \\
\text { d) more than two times }\end{array}$ & $\begin{array}{c}30 \\
45 \\
20 \\
5\end{array}$ & $\begin{array}{l}30 \% \\
45 \% \\
20 \% \\
5 \%\end{array}$ \\
\hline
\end{tabular}

Table number-1 depict that $37 \%$ children belong to 5-7 years, $33 \%$ children were from $>7$ years to 9 years, while, remaining 30 percent were $>9$ year to 10 years age category. Majority $56 \%$ children were male .Larger $61 \%$ children were under $1-3^{\text {rd }}$ class category, whereas ,5\%children were not enroll in formal education .Majority $75 \%$ children primary care giver was mother. $45 \%$ children were admitted first time in hospital whereas $30 \%$ were never admitted in hospital for any reason .

Section B: Assessment of post operative comfort in children admitted in post operative ward

Table 2: Level of comfort in post operative children $\mathbf{N}=\mathbf{1 0 0}$

\begin{tabular}{|c|c|c|c|}
\hline $\begin{array}{c}\text { Comfort Assessment } \\
\text { Tools }\end{array}$ & \multicolumn{2}{|c|}{$\begin{array}{c}\text { Comfort } \\
\text { score }\end{array}$} & \multirow{2}{*}{$\begin{array}{c}\text { Level of } \\
\text { Comfort }\end{array}$} \\
\cline { 2 - 3 } & Mean & SD & \\
\hline $\begin{array}{c}\text { Comfort observation } \\
\text { check list }\end{array}$ & 45.88 & 9.91 & $\begin{array}{c}\text { Moderate } \\
\text { discomfort }\end{array}$ \\
\hline $\begin{array}{c}\text { Comfort daises } \\
\text { (Right Now I feel: ) }\end{array}$ & 1.3 & 0.50 & $\begin{array}{c}\text { Feeling between } \\
\text { very bad and sort } \\
\text { of bad }\end{array}$ \\
\hline
\end{tabular}

Table 2-depicit that post operative children were having moderate discomfort $(45.88 \pm 9.91)$ as assessed by comfort observation check list.This finding goes with comfort assessed with comfort daises which involves a child's rating his or her comfort from one to four (very bad to very good) that post operative children averagely rated their comfort feeling between very bad and sort of bad. Both Comfort observation checklist and comfort daises were feasible in assessing level of comfort in children 


\section{Conclusion}

Comfort is important aspect of nursing care .Assessment of correct level of comfort will help in delivering effective nursing care to children. Instead of using long questionnaires it will be better to use observation check list and comfort daises for assessment of level of comfort in children. Asking long questions creates discomfort in children.

\section{References}

[1] Froehlich, M. A comparison of the effect of music therapy and medical play therapy on the verbalization behavior of

[2] pediatric patients. Journal of Music Therapy1984, 21 (1), $2-15$.

[3] Ellerton, M.L., \& Merriam, C. Preparing children and families psychologically for day surgery: an evaluation. Journal of Advanced Nursing 1994, 19, 1057-1062.

[4] Schmidt, L.R. Hospitalization in children. Cambridge Handbook of Psychology, Health and Medicine. Edited by Andrew Baum, Stanton Newman, John Weinman, Robert West, Chris McManus. Cambridge University Press. 1997

[5] Kain Zn, Mayes lc, O'connor tz, Cicchetti Dv: Preoperative anxiety in children. Predictors and outcomes. Arch Pediatr Adolesc Med; 1996, 150:123845.

[6] Kolcaba, K. An introduction to comfort theory. 2010. In The comfort line. (Retrieved January 02, 2014) from http://www.thecomfortline.com/home/intro.html 